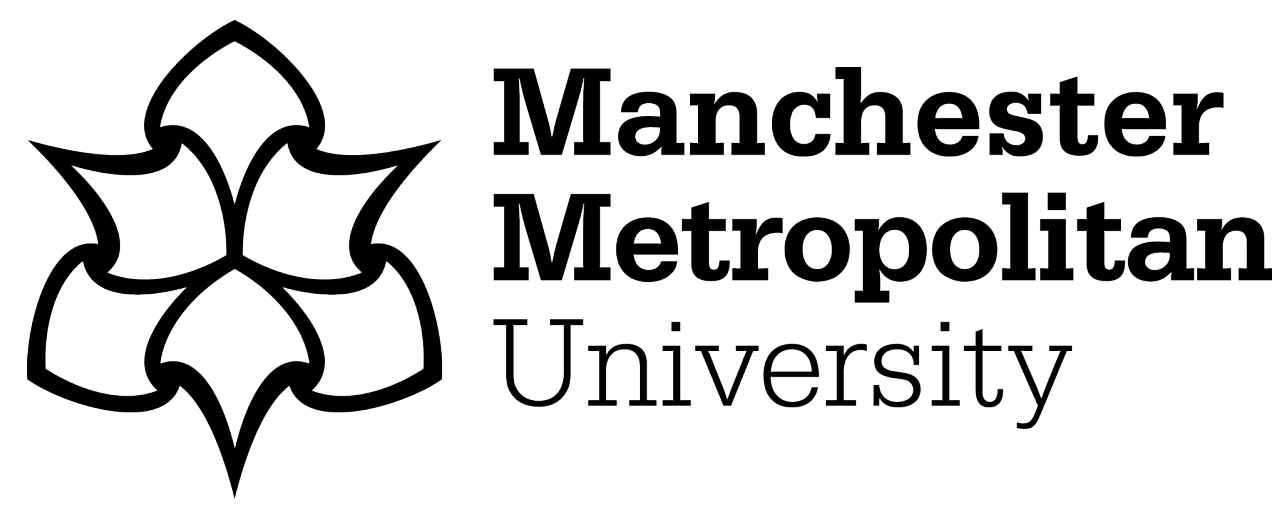

Kelly, Dominic (2020) The Necessity of Thinking Historically - Heidegger After Nietzsche. Journal of the British Society for Phenomenology, 51 (2). pp. 162-173. ISSN 2332-0486

Downloaded from: https://e-space.mmu.ac.uk/627872/

Version: Accepted Version

Publisher: Taylor and Francis

DOI: https://doi.org/10.1080/00071773.2020.1703281

Please cite the published version 


\section{THE NECESSITY OF THINKING HISTORICALLY - HEIDEGGER AFTER NIETZSCHE}

The intention of this paper is to draw out the movement in Heidegger's thought as it occurs in the 1930s. What I will try to show is that Heidegger's thought moves from a properly philosophical engagement regarding the question of being to a thinking of being that is otherwise than metaphysical - what Heidegger terms being-historical thinking. I will identify a particular moment in the 1930s (as is revealed in the Black Notebooks ${ }^{\mathrm{i}}$ ) when the need for such a turning in Heidegger's thinking arises and trace this need to the problem of how to think the historical occurrence of being. In doing so, I will negotiate my way between Heidegger's engagement with both the thinker Friedrich Nietzsche and the poet Friedrich Hölderlin as it occurs in the mid-to-late '30s. ${ }^{\text {ii }}$ During this period in his thinking Heidegger's texts reveal a two-fold struggle to break free from the metaphysical traces that were still noticeable in his own philosophy. On the one hand, through his engagement with Hölderlin, we see Heidegger trying to draw out the possibilities that lie within poietical language as a way of opening up a new relation to being and thereby the prospect of an other history to be established beyond the horizon of the Western tradition of metaphysical thought. On the other hand, in his confrontation with Nietzsche, Heidegger sets himself that most difficult of tasks: trying to distance his own thought (and ours) from that of Nietzsche. The difficulty here for Heidegger lies in the fact that not only is Nietzsche the last great thinker of the metaphysical tradition and thus both encapsulates it and signals its end, but that in trying to distance our thought from Nietzsche's we are also trying to distance ourselves from the thinker who is closest to us. What I hope to show is that it is out of this confrontation with Hölderlin and Nietzsche that Heidegger's non-public writings of the late '30s and early 1940s take on their more fragmentary style. It is my contention that this fragmentary way of thinking, which tries to both distance itself from Nietzsche's and at the same time give voice to a properly historical way of thinking being, is not only indebted to Nietzsche's own thought (a point Heidegger would readily accept) but that this is reflected formally in Heidegger's own texts. However, as this path of thought (that in moving away from Nietzsche actually moves towards him) can only be understood as a response to the historical problem of nihilism as the final stage of the history of metaphysics, then it is to the problem of nihilism that I shall first turn and that as it is rendered by the great thinker of nihilism - namely, Friedrich Nietzsche. 
Before turning directly to the question of nihilism, however, I think it will prove useful to give a little context to Heidegger's thinking in order to show how the movement in his thought reflects a change in how he thinks history is to be thought as the Western metaphysical tradition draws to a close. For Heidegger the history of the West thus far, from its inception in the thought of the ancient Greek philosophers to its culmination in Nietzsche's determination of being as Will to Power, is to be understood as the history of the forgetting of being (Seinsvergessenheit). ${ }^{\text {iii }}$ Signally, that this is the case only comes to light as this history draws to a close, and in so doing the possibility of a new relation to being and thus a another beginning (anderer Anfang) or history also comes into view. This is what Heidegger refers to as the 'turning' that occurs within being, the moment when history thus far is revealed out of its origins as determining being in such a way that it fails to do justice to being's essential nature. It is also the moment when thought is called to think being more authentically. iv

Moreover, this Western metaphysical tradition, as the forgetting of being, is a history that ends in modernity and is revealed as such in the incapacity of philosophy to any longer think about the nature of being. As we shall see, this incapacity is best exemplified for Heidegger in the thought of Nietzsche, a thinker whose work Heidegger regards as both compelling and as bringing metaphysics to its conclusion insofar as Nietzsche constructs a metaphysics of pure subjectivity. What Heidegger means by this is that Nietzsche's thought is the ultimate expression of what philosophy has attempted to articulate since its inception in ancient Greek thought, i.e., the beingness (Seiendheit) of beings (Seiendes). That the metaphysical tradition thinks being (Sein) in these terms means it reduces the truth of what is to the way an entity presents itself, as a result of which the meaning of being as such goes increasingly unthought. This thoughtlessness reaches its climax in Nietzsche's notion of Will to Power, which thinks being in terms of beings understood as pure loci of power, a determination that reduces life to an immanent presence by removing anything beyond life towards which it can be directed. Thus the history of metaphysics ends in nihilism, a point in the history of Western thought when 'there is nothing going on with being'. Hence, for Heidegger nihilism is the culmination of Western thought's historical failure to do justice to being - that is, to maintain an openness to being's hidden possibilities. 
However, Heidegger also suggests that the reason thought is unable to do justice to being lies within the origins of metaphysical thinking itself as it arises in and as Greek philosophy. It is out of these origins, as has been noted succinctly elsewhere, that Heidegger thinks the history of the West hitherto 'has wandered into a crisis of withdrawal'. ${ }^{\mathrm{v}}$ What this means for thought is that what is appears to be self-given and immediate and the sheer wonder at the presence of things that belongs to the ancient Greeks (and gives rise to the Western tradition) has disappeared. Why this should be the case is that today we no longer experience beings as the Greeks did, that is, aletheically. ${ }^{\mathrm{vi}}$ To say that the Greeks experienced beings aletheically is to say that for the Greeks beings in their beingness emerge into presence (from out of hiddenness). However, Heidegger argues, in bringing this experience to thought the Greeks fail to account for the hiddenness from which beings emerge and think the beingness of beings solely in terms of presencing. This determination gives rise to and shapes the Western tradition, whereby beings are thought in terms of presence and that from which they emerge into presence, namely being, is forgotten. In modernity, this view of beings is apparent in the sciences, which approach beings as objects insofar as they are strewn of any temporal relations and as simply lying present before the knowing subject. The truth of beings on this count is a-historical, and a relation to being as such is missing from the picture.

The implicit danger here is that not only does thought not do justice to being, but that the human being as such runs the risk of being reduced to an object that has no meaning beyond its scientific calculability. Consequently, Heidegger thinks, we need to retrieve a proper sense of being and thus a properly historical sense of ourselves, in order to open up ourselves to something beyond the immanence of our own being. Heidegger thinks that to do this requires that we establish an open relation to being whereby the hiddenness that is essential to the emergence of beings into presence comes to light in itself. For Heidegger, it is this hiddenness or withdrawal of being that provides 'food for thought', that is, that opens up a path within being along which thought can travel and thereby humanity can have a meaningful destiny towards which it can comport itself. It is for this reason that Heidegger turns to poetry and to the poetic world of Friedrich Hölderlin in particular, as in the latter Heidegger discovers the possibility of opening up a properly historical dimension for thought, that is, of doing justice to being. And it is against this backdrop that we can understand the need to turn to Heidegger's confrontation with Nietzsche as the thinker of nihilism and the need to try to distance our own thinking from his.

\section{Nietzsche and the Problem of History}


Nietzsche opens his second Untimely Meditation, entitled On the Uses and Disadvantages of History for Life with a quotation from a letter Goethe sent to Schiller which says: "In any case, I hate everything that merely instructs me without augmenting or directly invigorating my activity." vii In doing so, Nietzsche throws light on two essentially related matters that need to be thought through if we are to gain any proper insight into the origin and nature of nihilism as it has arisen as an illness that afflicts modern European humanity as well as gain any kind of perspective on how we are to respond to it now that it has arrived. The first of these two matters is the notion of history which Nietzsche views as a far more complicated state of affairs than is rendered by what he calls modern critical historians. The second matter is the nature of the style of thinking that tries to get to the truth of and is intertwined with this history. I do not intend here to go into the complex nature of these two notions as Nietzsche thinks them but I shall draw out a couple of important points relating to each.

Firstly, history for Nietzsche is not simply something that can be objectively present to thought, its true meaning at any one time simply discoverable if only we have enough facts about an event with which a particular interpretation about these facts coincides. History is rather to be thought of as effective history (and Nietzsche here owes a debt to Hegel). ${ }^{\text {viii }}$ By this Nietzsche is saying that if we wish to know the nature of reality, if we wish to know the nature of human existence, of who we are and how we came to be here then we need to look to effective history as leading to the concretion of our current situation. For the modern European this means that if one is to understand oneself one needs to look back at the unfolding history of Europe. To have some grasp of who I am and how I got here depends on understanding the supersession of tragedy by philosophy in ancient Greece, for example. However, for Nietzsche this is not so much a question of knowledge as an attempt at trying to recognize how the historical currents in which one finds oneself have developed and of orientating oneself in relation to this development. For Nietzsche this means that what we would normally think of as history is not so much a series of factual events but the unfolding of human activity in the world. Thus what moves history is life, and so the factual events of history can only be viewed from the perspective of life in the same way a snake views its sloughed off skin - as dead matter. And our understanding of the role of human life in the historical process cannot be reduced simply to its intellectual capacities: the human being has to be understood as concretely immersed in the world. Thus Nietzsche differs here from Hegel in his understanding of effective history insofar as he does not see history purely in terms of conscious development but as a finite, mostly unconscious creative process. History 
is thus understood as the movement of life through time that is given rise to through (mostly unreflective) human action. If we want to come to terms with who we are and how we got here (not to say where we are going) then we need to situate ourselves in a properly historical way as belonging to an ongoing process of (ultimately unknowable) change.

The second and related point has to do specifically with how exactly we situate ourselves historically. If history unfolds out of life as a creative process of change rather than a reflective process of epistemological progression then how does one respond thoughtfully to its concrete demands? One might be tempted to respond 'philosophically' but Nietzsche sees a difficulty here. For Nietzsche philosophical (not to say scientific) thinking tries to give us an objective view of life and in doing so it fails to grasp the very becoming of life that is made concrete in its historical unfolding. Further, this objective or neutral perspective on life has been the desire of philosophy from its earliest stages. In his 'How the True World Finally Became a Myth ${ }^{\text {ix }}$ Nietzsche outlines the path this desire has taken pointing to Plato $^{\mathrm{x}}$ as the thinker who from philosophy's earliest stages posits the notion of a true world set over and against the world of becoming from which vantage point the philosopher is able to make objective judgements about life. The pursuit of the true world or of objective truth thus becomes the purpose of philosophy to an extent which leads Nietzsche to say of philosophers that 'nothing real has ever left their hands alive'. ${ }^{\text {i }}$ That is, philosophy does not serve life but stands above it, taking a God-like perspective.

The problem that arises here for Nietzsche is that if we want to understand our current historical situation then we need to view it from the perspective of life, out of which it arises. But philosophy can only respond from an ahistorical perspective and so the question arises as to how philosophy responds to the emergence of historical problems from a perspectiveless, objective viewpoint? Indeed, the problem for the critical thinker is to try to pass judgment on a problem that originally arises out of philosophical thought itself: that the philosophical pursuit of truth, which was once beneficial to life and the movement of history, is now no longer even able to relate to this movement.

Now the problem that Nietzsche tries to make manifest in his thinking here is the problem of nihilism. Nietzsche defines nihilism when he says that 'the highest values devaluate themselves', by which he means that those absolute values that have been applied to life (for example, the pursuit of objective truth) and in pursuit of which European civilization has been living throughout its history can be shown in modern critical thought (and are shown in 
Nietzsche's thought) to be without foundation (at least outside of life itself). To which Nietzsche adds 'the aim is lacking; "why" finds no answer'. Thus when we discover that our absolute values are in fact historically conditioned and do not exist outside of this history then the purpose of human existence as somehow transcendent of its current historical situation is unsustainable - and thus the individual is increasingly alienated from her world, which is to say that she does not see her actions as being purposeful or effective. Consequently, the problem that Nietzsche confronts here is that our history is an illness from which we suffer but which we are unable to bring to light as we no longer think from out of this history. If however we were able to think historically and to somehow bring the problem of nihilism to light, then that in itself would in some way help us to at least diagnose the malady that is nihilism and open up the possibility of addressing ourselves to it. What this requires is a change in our style of thinking, Nietzsche says, a notion to which I shall now turn.

Give what I have just outlined, that reason will not help us cope with the problem of nihilism hardly needs saying as it is reason that limits our understanding of history as arising out of life. Thus we need a new style of thinking, Nietzsche claims, a thinking that is historical in nature and will somehow allow us to respond to the contingencies of our current historical situatedness, perhaps even opening up new horizons towards which we can once more live meaningful lives. This means for Nietzsche properly historical horizons created out of properly historically experienced existences. So this new style of thinking needs to somehow jolt us out of our detached way of thinking about the world and force us to take up a view of the world from out of life itself, a view that allows us to look to the past and the future in order to make sense our present situation and thereby to effect it.

To this end in the Twilight of the Idols Nietzsche says:

I am often asked why I bother writing in German: my worst readers are in my homeland. But who says that I even want to be read these days? - To create things that stand the test of time; striving for a little immortality in form, in substance - I have never been modest enough to demand less of myself. I am the first German to master the aphorism; and aphorisms are the forms of 'eternity'; my ambition is to say in ten sentences what other people say in a book - what other people do not say in a book. ${ }^{\text {ii }}$ 
Now Nietzsche is a thinker who could never be described as systematic. His thought finds a home in aphorisms, fragments, what we might call extended-fragments and in his Thus Spoke Zarathustra he writes a work that is as difficult to define as it is to know how to respond to. It would be perhaps best to say of Nietzsche style of writing that it is fragmentary to the extent that it is a continuous attempt to get to things themselves without the sediment of traditional conceptuality getting in the way. A continuous attempt to grasp life away from the corpse-like grip of philosophy. Thus Nietzsche's fragments of thought tend to provoke the reader, to move or effect the reader in terms of their brutal honesty, their unpleasantness, their humour and so forth. And so they are attempts at moving the reader, at shaking her out of her neutral, rational perspective on things and instead trying to get her to catch a glimpse of life from a historical perspective (and thereby understanding life in terms of human action). We can see this if we look at a familiar fragment from The Gay Science:

The madman jumped into their midst and pierced them with his eyes. 'Whither is God?' he cried; 'I will tell you. We have killed him - you and I. All of us are his murderers ... Here the madman fell silent and looked again at his listeners; and they too were silent and stared at him in astonishment. At last he threw his lantern on the ground and it broke into pieces and it went out. 'I have come too early', he said then; my time is not yet, this tremendous event is still on its way... xiii

This provocative pronouncement, that God is dead - and if it is suitably effective - thrusts the reader into the current of history. It speaks to the past (that our goals are illusions that we have inherited); it speaks to the present (that our existences are thereby devoid of meaning); and it speaks to the future (of the need to make life itself the basis of the meaning of existence). Nietzsche also adds the proviso that his words are untimely, that they speak directly out of history and that they will have to wait for a hearing (when we are able to respond to them in other than a purely rational manner). In attempting to catch the historical movement of life in this way Nietzsche not only seeks to shift the focus of our understanding of things from the privileged God-like view of traditional philosophy but he tries to replace it with the finite perspective of life (thought as constantly becoming). This in turn opens up the question of what in truth it means to exist as a modern individual and points the individual's active engagement with her world as the source of a possible response to this question.

\section{Heidegger's Confrontation with Nietzsche}


One thinker who was able to hear Nietzsche's words is Martin Heidegger, who follows Nietzsche in recognizing modernity as the age of nihilism. However, Heidegger interprets nihilism differently, he sees it in terms of a thinking that is reduced to thinking of being purely in terms of beings, and beings solely in terms of making them present (for the human being). On this interpretation, nihilism brings to an end a course of history that originates in ancient Greek philosophical enquiry into the nature of being as such but which has descended into a complete forgetting of this questioning in favour of understanding things in terms of that which can be re-presented in human thought. So the task Heidegger sets himself in his first major work - Being and Time - is to ground philosophical thinking on a more temporal, that is, historical basis and thereby to open up the question of being through an examination of the human being understood as Dasein. ${ }^{\text {xiv }}$ That is, what Heidegger seeks in Being and Time (amongst other things) is a thinking that can reveal being in the sense of a presencing that in itself allows beings to become present.

However, and as is by now well known, Heidegger tells us in Letter on Humanism ${ }^{x v}$ (written in 1946 and revised for publication in 1947) that the third division of the first part of Being and Time was held back because language failed to think what Heidegger was trying to say there. And what Heidegger was trying to say there is that the truth of Dasein's being can only be thought in terms of its coming to be from out of being as such. And that talking about this phenomenon in terms of Dasein transcending toward an horizon of being (as he does in Being and Time) runs the risk of making this horizon into an object of thought, turning Dasein into a thinking subject and thereby thinking Dasein and being from out of the language of traditional metaphysics.

What was needed was a new approach to thinking being and the point at which this thought occurs historically is revealed in Heidegger's Black Notebooks. In a note from 1932 Heidegger says:

Today (March 1932) I am in all clarity at a place from which my entire previous literary output ... has become alien to me. Alien like a path brought to an impasse, a pass overgrown with grass and vegetation - a path which yet retains the fact that it leads into Da-sein as temporality. A path whose edges stands much that is 
contemporary and mendacious - often in such a way that these 'path markings' are taken as more important than the path itself. ${ }^{\text {xvi }}$

Now this certainly sounds like an epiphany of a sort. That is, it certainly sounds like Heidegger has come to a point in his thinking in which he recognizes that perhaps a trace of the metaphysics of presence still attaches itself to his thought and that in recognizing it he opens up the possibility of finding a way beyond it. But what form his thought should take at this point Heidegger seems to be at a loss pinpoint, concluding his quotation with the plaintive 'Yet why still record this, since to me myself the question is becoming ever more problematic'. However, only a few weeks later we get an idea of what this thinking might consist in when Heidegger says that 'the task is now: to win back the beginning - to question again within its most intrinsic questions'. ${ }^{\text {xvii }}$ And then a little later still he says that this winning back of the beginning involves thinking in a struggle 'over the grasp of the beginning and over the acknowledgement of the unavoidableness of the act of beginning and thereby over the theme of a distant injunction - the catching up of the latter'. ${ }^{\text {xviii }}$

We can see in what Heidegger has to say here (as we saw with Nietzsche) the rudimentary moves in a stepping back into a properly historical thinking. But whereas Nietzsche steps back into history thought as arising out of becoming, Heidegger steps back into history as arising out of Dasein's ongoing relation to being - a considerable difference. But there are some similarities which show the difficulty Heidegger will go on to have in distinguishing his own thought from that of Nietzsche's. For example, Heidegger's thinking will point back to ancient Greek thinking as the first beginning of the history of the West, it will point to the present as nihilistic as a consequence of this very thinking, and it will seek to open up the possibility of moving beyond this history by holding out the prospect of a new beginning based on a thinking that overcomes this history.

Heidegger's recognition that his thought needs to tread a new path means he tries to work out what form his thinking should take throughout the rest of 1930s (and beyond) by thinking through Dasein's relation to being in a way in which being itself becomes more prominently focused on as the location of Dasein coming into the truth of its being (and so its historical situatedness) and Dasein itself moves increasingly out of focus and is thought more in terms of the human being. We also see Heidegger's thought on being develop along a path that introduces the historical notions of a first and an other beginning. A path which leads to the 
need to think being no longer in terms of an horizon towards which Dasein transcends but as a 'happening' (Ereignis) that provides the possibility for Dasein to make a decision about its own historical being. Further, such a happening needs to be understood in terms of a turning (Kehre) that takes place within being. This turning sees Dasein as thrown into the truth of being as an openness for which Dasein has the responsibility of somehow keeping open. And the truth of being is seen as arising through Dasein as that being which allows this truth to come into the open. In the interplay between the two (which necessarily involves (amongst other things) an ongoing hiddenness and unhiddenness of the truth of being itself) history itself is able to arise. And it is the hidden possibilities that lie within this occurrence of history that Heidegger seeks to bring to light in thought.

Now, from the mid 1930s, as he is working out how to think this turning within being, until the early-to-mid 1940s, Heidegger has the most intense engagement with the works of both Nietzsche and the German poet Friedrich Hölderlin. And it is my contention that not only does Heidegger's thinking about being change directly in relation to his engagement with these two thinkers, but that the way he uses language in his texts written in the late 1930s/early 1940s reflects this change in thinking (that is, in his non-public writings, for example Contributions to Philosophy and Mindfulness). Indeed, I think this change in Heidegger's language can be seen in the way that he attempts to distance his own thought from that of Nietzsche's and in the increasing influence Hölderlin's texts have on him - that is, this change can be seen in the movement away from a purely philosophical discourse towards an investigation of thought as otherwise than metaphysical. How does this happen?

To speak in purely positive terms to begin with, we can see in Heidegger's lecture course on Hölderlin from 1934-1935 which was published in English as Hölderlin's Hymns Germania and The Rhine that Heidegger appropriates some of the major themes that will eventually prove to be the matter to be thought through in his non-public texts, that is, the matter of what Heidegger terms his being-historical thinking. Most notably in Contributions to Philosophy, Heidegger takes from the Hölderlin lecture course the notion of a first and an other beginning. For Heidegger this notion marks the end of Western history as that which originates in ancient Greek thought (and ends in Nietzsche's thinking) and the opening up of the possibility of a new history at some point in the future. Indeed, Hölderlin's poetry - with its pronouncement that we live at a time when the ancient gods have fled and of a god who is coming - itself opens up a space that allows for a crossing over from the one beginning to the other. And, 
according to Heidegger, it is the task of the philosopher/thinker to keep this space open, to think historically, to bring to light that we live at a time when being has withdrawn itself from us (a time when we are undergoing nihilism). For Heidegger, this crossing is the site in which a people can come to make a decision about itself, can come to deliver itself over to a new fate.

So much for Hölderlin's contribution to Heidegger's being-historical thinking. In a slightly more negative sense, we can see in Heidegger's increasingly hostile attitude towards Nietzsche in the 1930s and 40s the attempt to shake himself free of Nietzsche's influence and thereby gain further insight into his own thinking. Now whilst in part this can be put down to political considerations at the time Heidegger's main concern with Nietzsche is in a confrontation with the last great thinker of the metaphysical tradition, a thinker in whose thought this tradition in fact attains its destiny. Indeed, it makes perfect sense from Heidegger's viewpoint that if we want to think something new then we need to distance ourselves from that thinker who is closest to us. And what comes to light in Heidegger's confrontation with Nietzsche in the lecture courses is that in thinking historically, Nietzsche gives himself over to thinking being as becoming, which in turn leads him to think that nihilism can be overcome if we make the Will To Power the basis of what Nietzsche terms a revaluation of values.

From this Heidegger takes the view that Nietzsche is a metaphysical thinker because Nietzsche thinks being in terms of the being of beings as a whole (as becoming). He views Nietzsche as the apotheosis of all metaphysical thinkers insofar as Nietzsche thinks becoming in terms of the Will to Power. Now to say, as Nietzsche does, that the world is Will to Power and nothing else is to say that the world, life, human beings, history, truth and everything else are the expressions or loci of a confluence of forces that are constantly seeking to overcome one another. For Nietzsche, once the death of God has been pronounced Will to Power becomes the meaning of existence and nothing lies outside it. When we then add to this notion Nietzsche's idea of the Eternal Recurrence of the Same, which views this reality of pure becoming as something that simply repeats itself ad infinitum, in a circularity that has no order and no meaning, then we see that Nietzsche's thought lays bare humanity's historical situation - the human being has come to its historical end in a universe which places no intrinsic value on anything. This is the thought that Nietzsche confronts his reader with and which we have to overcome if we are to overcome nihilism. For Heidegger, however, such a 
thought means that whatever comes into existence - be it in the past, the present or the future - is determinable in its ground. We cannot escape the history of metaphysics on this count but only come to terms with it.

Heidegger thinks history differently. History has to be thought out of Dasein's relation to being and Dasein is always to some extent in the dark about being. This happens both in terms of being always withholding itself from Dasein insofar as being is essentially selfconcealing and, certainly in the modern era, in terms of Dasein's forgottenness of being (Seinsvergessenheit) as such. ${ }^{\mathrm{xix}}$ Hence whatever comes to presence in history always does so in relation to that which essentially remains absent. One important consequence of this is that our relation to history is not determinable and so the possibility of a new relation to being and thus the opening up of a new history remains possible. Such a possibility belongs to thought attending to the truth of being, a truth which as 'that clearing of self-sheltering-concealing, in whose opening gods and men are enowned for their countering, enopens being as history.' ${ }^{\mathrm{xx}}$ For Heidegger such a thinking is tied to language thought poietically, there being something peculiarly suitable to the poetic word insofar as it can adapt itself to the saying of being and thereby hold out the possibility of setting Dasein and being on a new footing. I cannot talk about this notion of language here beyond saying that as language is 'the house of being' for Heidegger it is in language thought poietically that he sees a way beyond nihilism.

For the purposes of this paper what is notable about Heidegger's shift away from Nietzsche here is that in his attempts to think historico-poietically - especially in his non-public writing of the late ' 30 s and early ' $40 \mathrm{~s}$ - his thinking takes on a form that is itself indebted to Nietzsche's own form of historical thinking. And, for example, in Heidegger's Contributions to Philosophy this can be seen in both the form and the structure of what Heidegger tries to think there. We see thought coming to light in a fragmentary manner. What is thought is couched in a language that does not simply appeal to reason but requires the reader to return again and again to think through that which is to be thought. We see a thinking that is structured in such a way that one perspective is piled upon another with regard to that which it to be thought about. And most striking of all we see thought trying to give us a sense of the historical as it actually unfolds. Thus we see that in trying to distance himself from Nietzsche as an historical thinker, Heidegger, at least formally, thinks like Nietzsche. Of course, the histories that these two thinkers try to bring to light are thought differently. Nietzsche confronts his reader with an experience of nihilism that tries to provoke us to action. 
Heidegger reveals nihilism as the loss of an open relation to being and points us in the direction of poietical language as a possible way beyond this.

We can see in the following extract from the conclusion to Heidegger's Contributions to Philosophy in which he is talking about the origin of language, in fragmentary style:

Language is grounded in silence. Silence is the most sheltered measure-holding. It holds the measure, in that it first sets up measures. And so language is measuresetting in the most intimate and widest sense, measure-setting as essential enswaying of the jointure and its joining (enowning). And insofar as language is the ground of Da-sein, the measure lies in this and indeed as the ground of the strife of world and earth. ${ }^{\text {xxi }}$ 
'Specifically, I shall refer to Martin Heidegger, Überlegungen II-VI (Schwarze Hefte 1931-1938) Gesamtausgabe
94, ed. Peter Trawny (Frankfurt: Klostermann, 2014) translated by Richard Rojcewicz into English as Ponderings II-VI (Indiana: IUP: 2016).

ii For practical reasons the essay will be mainly focused on Heidegger's Auseinandersetzung with Nietzsche at the expense of his engagement with Hölderlin.

iii Seinsvergessenheit is how Heidegger understands the nature of nihilism. He describes it in the following way in GA 45, translated into English by R Rojcewicz \& A Schuwer as Basic Questions of Philosophy: Selected 'Problems' of 'Logic' (Indianapolis: Indiana UP, 2004) p 159: "Beings are, but the being of beings and the truth of being and consequently the being of truth are denied to beings. Beings are, and yet they remain abandoned by being and left to themselves so as to be mere objects of our contrivance. All goals beyond men and peoples are gone, and, above all, what is lacking is the creative power to create something beyond oneself. The epoch of the highest abandonment of beings by being is the age of the total questionlessness of being."

iv This is to say that language speaks out of silence and is grasped only insofar as it illuminates that which it is not. To undergo an authentic experience of language is therefore to be able to hear what language has to say in bringing being to light, in bringing into the truth of the word that which is. For the human being to undergo such an experience of language it must be given over to language as that through which being happens, to experience what Heidegger terms Ereignis. In 'On the Way to Language' Heidegger deals in detail with this idea of authentic thinking, leading the reader from the view that the human being is that being who is distinguished by language (the zoon logon echon as it is traditionally rendered), to that being who finds herself at home within language, that is, within the unfolding coming-to-presence of being in the saying of the word. In other words, the human being does not possess language as an attribute but rather 'is' through language. For a thorough explication of Heidegger on language see GA 12 translated into English as by Peter D Hertz as On the Way to Language (San Francisco: Harper and Row, 1971).

$\checkmark$ Jennifer Anna Gosetti-Ferencei, Heidegger, Hölderlin, and the Subject of Poetic Language: Towards New Poetics of Dasein (New York: Fordham UP, 2004) p 31.

vi Heidegger says of the notion of aletheia in The End of Philosophy and the Task of Thinking that: Alêtheia, unconcealment as the clearing of presence, is not yet truth. Is aletheia then less than truth? Or is it more, because it first grants truth as adequatio and certitudo, because there can be no presence and presenting outside the realm of the clearing'? Martin Heidegger, Basis Writings trans. \& ed. David Farrell Krell (London: Routledge, 1993) p 446. Heidegger is here stating that whilst any claim that for the Greeks truth was understood aletheically would be erroneous (a claim Heidegger maintained for much of his philosophical life), it is only out of an experience of unconcealment that the Greek notion of truth can take hold. Thus it would be untenable to claim that there was a transformation in the Greek notion of truth from unconcealment to truth thought as correctness (orthotēs) of statements or representations.

vii Friedrich Nietzsche, Untimely Meditations trans. RJ Hollingdale (Cambridge: CUP, 1997) p 59.

viii For the sake of clarity it should be noted what Nietzsche means by 'effective history'. For the Germans history can be thought in two ways. History thought as Historie is what we generally think of as the content of historiology, that is, the actual events that happen in historical time. Effective history, that is, history thought as Geschichte, on the other hand, is the actual happening of history that allows these events to take place.

${ }^{i x}$ Friedrich Nietzsche, Twilight of the Idols, trans. Judith Norman (Cambridge: CUP, 2005) p 171.

x This statement is revelatory of something essential to Nietzsche's thinking on nihilism. Plato, in stamping being onto becoming, is the embodiment of the kind of person who - rather than merely passively standing by on the look-out for truth - is actively involved in creating it, in bestowing it as a value upon the world by positing it as the meaning of human existence. Thus Plato is a prime example of what could be argued is the central thought (alongside The Eternal Return of the Same) of Nietzsche's work, namely, (the) Will to Power, a prime example of what Nietzsche means when he says that 'to impose upon becoming the character of being that is the supreme Will to Power'. The Will to Power, trans. W Kauffman \& RJ Hollingdale (New York: Vintage Books, 1968) § 617.

${ }^{x i}$ Twilight of the Idols, $\mathrm{p} 167$.

xii Twilight of the Idols, p 223.

xiii Friedrich Nietzsche, The Gay Science, trans. W Kauffman (New York: Vintage Books, 1974) § 125.

xiv In Being and Time Heidegger uses Dasein to refer to what we would normally call the ' $I$ ' and which the philosophical tradition calls the 'soul' or 'ego' or 'self'. In doing so, Heidegger seeks to overcome the tendency 
to reify the being of the human being that comes from thinking of it in ontic terms, that is, from thinking of it in terms of the categorial determinations of entities by which they are traditionally distinguished from each other. This allows Heidegger to bring out the ontological nature of the human being and beings in general. Cf. for example, Being \& Time $\mathrm{p} 32$.

${ }^{x v}$ Cf. Brief über den Humanismus translated by Frank A. Capuzzi in Basic Writings, trans. \& ed. by David Farrell Krell (London: Routledge, 1993).

xvi GA 94) p 15.

xvii Ibid. p 39.

xviii Ibid. p 48.

xix To this end Heidegger says: "Beings are, but the being of beings and the truth of being and consequently the being of truth are denied to beings. Beings are, and yet they remain abandoned by being and left to themselves so as to be mere objects of our contrivance. All goals beyond men and peoples are gone, and, above all, what is lacking is the creative power to create something beyond oneself. The epoch of the highest abandonment of beings by being is the age of the total questionlessness of being." [BQP 159]

xx Martin Heidegger GA 65 translated into English by P Emad \& K Maly as Contributions to Philosophy (From Enowning) (Indianapolis: IUP, 1999) p 298.

xxi Ibid. p 510. 